\title{
Highly Stable and Active Pt/Nb-TiO 2 Carbon-Free Electrocatalyst for Proton Exchange Membrane Fuel Cells
}

\author{
Shuhui Sun, ${ }^{1,2,3}$ Gaixia Zhang, ${ }^{1,2,3}$ Xueliang Sun, ${ }^{2}$ Mei Cai, ${ }^{1}$ and Martin Ruthkosky ${ }^{1}$ \\ ${ }^{1}$ General Motors Global Research and Development Center, Warren, MI 48090-9055, USA \\ ${ }^{2}$ Department of Mechanical and Materials Engineering, The University of Western Ontario, London, \\ ON, Canada N6A $5 B 9$ \\ ${ }^{3}$ Institut National de la Recherche Scientifique-Énergie, Matériaux et Télécommunications, \\ Université du Québec, Varennes, QC, Canada J3X 1S2
}

Correspondence should be addressed to Xueliang Sun, xsun@eng.uwo.ca and Mei Cai, mei.cai@gm.com

Received 13 March 2012; Accepted 30 May 2012

Academic Editor: Tanaji P. Gujar

Copyright (c) 2012 Shuhui Sun et al. This is an open access article distributed under the Creative Commons Attribution License, which permits unrestricted use, distribution, and reproduction in any medium, provided the original work is properly cited.

The current materials used in proton exchange membrane fuel cells (PEMFCs) are not sufficiently durable for commercial deployment. One of the major challenges lies in the development of an inexpensive, efficient, and highly durable and active electrocatalyst. Here a new type of carbon-free $\mathrm{Pt} / \mathrm{Nb}-\mathrm{TiO}_{2}$ electrocatalyst has been reported. Mesoporous $\mathrm{Nb}^{-\mathrm{TiO}_{2}}$ hollow spheres were synthesized by the sol-gel method using polystyrene (PS) sphere templates. Pt nanoparticles (NPs) were then deposited onto mesoporous $\mathrm{Nb}-\mathrm{TiO}_{2}$ hollow spheres via a simple wet-chemical route in aqueous solution, without the need for surfactants or potentiostats. The growth densities of $\mathrm{Pt} \mathrm{NPs}$ on $\mathrm{Nb}-\mathrm{TiO}_{2}$ supports could be easily modulated by simply adjusting the experimental parameters. Electrochemical studies of $\mathrm{Pt} / \mathrm{Nb}-\mathrm{TiO}_{2}$ show much enhanced activity and stability than commercial E-TEK Pt/C catalyst. PtNP/Nb-TiO 2 is a promising new cathode catalyst for PEMFC applications.

\section{Introduction}

Proton exchange membrane fuel cells (PEMFCs) have been attracting much attention as an alternative clean energy source because of their high efficiency, high power density, and low pollution [1]. However, there are still challenges, such as, low catalytic activity, low durability, and high cost, which are hindering the commercialization of PEMFCs [2]. For automotive applications, PEMFCs must be durable enough for $\sim 5,000$ driving hours (i.e., 10 years) in vehicles [2]. The loss of platinum (Pt) electrochemical surface area (ECSA) over time due to carbon support corrosion and $\mathrm{Pt}$ dissolution/aggregation/Oswald ripening is considered one of the major contributors to the degradation of fuel cell performance [3]. Usually, carbon black (Vulcan XC-72) is used as Pt catalyst support in PEMFCs. However, carbon black is known to undergo electrochemical oxidation under a fuel cell operating environment, especially at potentials above $0.9 \mathrm{~V}$ (1), leading to a loss of Pt and fuel cell performance degradation $[4,5]$ :

$$
\mathrm{C}+2 \mathrm{H}_{2} \mathrm{O} \longrightarrow \mathrm{CO}_{2}+4 \mathrm{H}^{+}+4 \mathrm{e}^{-} .
$$

Therefore, it is necessary to explore noncarbon catalyst support materials with the current fuel cell operating strategy. Some metal oxides have been studied by different research groups as alternative catalyst support materials, such as, substoichiometric titanium oxide $[6,7]$, indium tin oxide [8], niobium-doped titania [9], tungsten oxide [10, 11], and tin oxide [12]. Among these, niobium-doped titania ( $\mathrm{Nb}-$ $\left.\mathrm{TiO}_{2}\right)[9,13-15]$ is a particularly promising candidate. $\mathrm{TiO}_{2}$ is notable for its photocatalytic and strong metal support interaction (SMSI) properties $[16,17] . \mathrm{TiO}_{2}$ is also readily available, cheap, and nontoxic [18]. The use of $\mathrm{Nb}$ doping has been found to significantly improve the electrical conductivity of $\mathrm{TiO}_{2}$, which allows its use in electrocatalytic reactions [14]. In this study, we present a simple wet-chemical route to 
grow Pt nanoparticles (NPs) on mesoporous $\mathrm{Nb}-\mathrm{TiO}_{2}$ hollow spheres, with controlled Pt loadings, in environmentally friendly aqueous solution. $\mathrm{PtNPs} / \mathrm{Nb}-\mathrm{TiO}_{2}$ catalysts exhibit higher catalytic activity for ORR and better stability than the benchmark E-TEK commercial Pt/C catalysts.

\section{Materials and Methods}

2.1. Chemicals. Hexadecyltrimethylammoniumbromide (HATB), titanium (IV) isopropoxide (TTIP), niobium (V) ethoxide ( $8 \mathrm{~mol} \%$ ), ethanol, $\mathrm{HNO}_{3}$, hexachloroplatinic acid $\left(\mathrm{H}_{2} \mathrm{PtCl}_{6} \cdot 6 \mathrm{H}_{2} \mathrm{O}, 99.95 \%\right)$, and formic acid $(\mathrm{HCOOH}, 98 \%)$ were purchased from Sigma-Aldrich. Aqueous latex (mean diameter $200 \mathrm{~nm}$ ) suspension (10 wt\%) was purchased from Duke Scientific. All chemicals were used as received without further purifications. All solutions were prepared with ultrapure water purified with the Millipore water system $\left(18.2 \mathrm{M} \Omega \cdot \mathrm{cm}\right.$ resistivity @ $\left.25^{\circ} \mathrm{C}\right)$.

2.2. Preparation of Mesostructured $\mathrm{Nb}-\mathrm{TiO}_{2}$ Support. The mesostructured $\mathrm{Nb}-\mathrm{TiO}_{2}$ support was prepared according to the method described in [15]. Briefly, $0.015 \mathrm{~g}$ of HATB, $14.7 \mathrm{~mL}$ of aqueous latex suspension, and $105 \mathrm{~mL}$ of ethanol were added in a PTFE beaker, and then the solution was stirred vigorously for $30 \mathrm{~min}$ while $\mathrm{HNO}_{3}$ was added to adjust the $\mathrm{pH}$ to 3 . A second solution was prepared by adding the precursors, $6.9 \mathrm{~mL}$ of TTIP and $0.5 \mathrm{~mL}$ niobium (V) ethoxide to $100 \mathrm{~mL}$ of ethanol. The second solution was added to the stirred latex-surfactant mixture using a peristaltic pump at a rate of $1 \mathrm{~mL} / \mathrm{min}$. The resulting suspension was processed using a Buchi B-290 spray drier to produce a fine white powder, consisting of the $\mathrm{Nb}-\mathrm{TiO}_{2}$ and latex template, which was followed by heat treatment at $500^{\circ} \mathrm{C}$ for $2 \mathrm{~h}$ under argon in order to remove the latex template. To obtain rutile phase [19], the as-synthesized $\mathrm{Nb}-\mathrm{TiO}_{2}$ powder were heated at $1050^{\circ} \mathrm{C}$ under hydrogen.

\subsection{Preparation of PtNPs/Mesostructured $\mathrm{Nb}-\mathrm{TiO}_{2}$ Compos-} ite. The $\mathrm{Pt}$ nanoparticles were synthesized by the formic acid method as described in the literature [20-22]. The asprepared mesostructured $\mathrm{Nb}-\mathrm{TiO}_{2}$ was used as the supporting substrate for Pt deposition. For the deposition of $40 \mathrm{wt} \%$ $\mathrm{Pt}$ on $\mathrm{Nb}-\mathrm{TiO}_{2}, 22 \mathrm{mg}$ of $\mathrm{H}_{2} \mathrm{PtCl}_{6} \cdot 6 \mathrm{H}_{2} \mathrm{O}(7.5 \mathrm{mg} \mathrm{Pt})$ and $1 \mathrm{~mL}$ of $\mathrm{HCOOH}$ are added to $20 \mathrm{~mL}$ of water. $\mathrm{Nb}-\mathrm{TiO}_{2}$ $(11.25 \mathrm{mg})$ was then dispersed in the above solution by mild ultrasonication for $30 \mathrm{~min}$. After this initial dispersion, the solution is heated to $80^{\circ} \mathrm{C}$ and kept at this temperature for $30 \mathrm{~min}$. After the reaction is completed, the product was washed thoroughly with deionized water and then dried in a vacuum oven at $60^{\circ} \mathrm{C}$.

2.4. Physical Characterization. The morphologies and microstructures of the as-prepared samples were examined by scanning electron microscope (SEM, Hitachi S-4800) operated at $5 \mathrm{kV}$, and transmission electron microscopy (TEM, JEOL JEM-2100) operated at $200 \mathrm{kV}$. X-ray diffraction (XRD) patterns were recorded on a Bruker D8 Advance diffractometer equipped with a $\mathrm{Cu} \mathrm{K} \alpha$ radiation source. Xray photoelectron spectroscopic (XPS) analysis was carried out in a VG ESCALAB 220iXL, using monochromated $\mathrm{Al} \mathrm{K \alpha}$ source $(1486.6 \mathrm{eV})$, at a base pressure of $2 \times 10^{-9} \mathrm{mbar}$. Highresolution spectra were obtained at a perpendicular takeoff angle, using a pass energy of $20 \mathrm{eV}$ and steps of $0.05 \mathrm{eV}$. All the binding energies were calibrated by referring to the C1s line at $284.8 \mathrm{eV}$ from adventitious carbon. After Shirley background removal, the component peaks were separated using the public domain XPS Peak program version 4.1 [23].

2.5. Electrode Preparation. The electrochemical measurements were conducted at room temperature in a standard three-electrode cell using a glassy carbon (GC) rotating disk electrode (RDE) setup with a voltalab model PGZ100 potentiostat (Radiometer Analytical) and rotation control (MSR, Pine Instruments). A Pt wire served as the counter electrode, with a saturated calomel electrode (SCE) as the reference which was separated from the working electrode compartment by a closed electrolyte bridge. All potentials in this study, however, are referenced to the reversible hydrogen electrode (RHE). The working electrode was prepared with a procedure similar to the one reported previously [8]. Typically, $5 \mathrm{mg}$ catalyst was sonically mixed with $5 \mathrm{~mL} \mathrm{H}_{2} \mathrm{O}$ / isopropanol/Nafion (5/1/0.0017 in volume ratio) for $12 \mathrm{~min}$ to make a suspension. GC disk electrodes ( $5 \mathrm{~mm}$ diameter, $0.196 \mathrm{~cm}^{2}$, Pine Research Instrument) served as the substrate and were polished to a mirror finish. An aliquot of catalyst suspension was pipetted onto the carbon substrate, resulting in approximate Pt loadings of $13 \mu \mathrm{gPt} \mathrm{cm}{ }^{-2}$ for all catalysts. The catalyst films were dried under flowing nitrogen $\left(\mathrm{N}_{2}\right)$ at room temperature.

2.6. Electrochemical Measurements. The working electrode, in an argon (Ar) purged $0.1 \mathrm{M} \mathrm{HClO}_{4}$ solution at room temperature, was first cycled 200 times between 0 and $1.1 \mathrm{~V}$ at a $1 \mathrm{~V} / \mathrm{s}$ scan rate in order to produce a clean electrode surface. The cyclic voltammetry (CV) measurements were conducted by cycling the potential between 0 and $1.1 \mathrm{~V}$, with a scan rate of $20 \mathrm{mV} / \mathrm{s}$. The electrochemical surface areas (ECSA) were calculated from the hydrogen adsorption peak of the CV. The oxygen reduction reaction (ORR) experiments were performed in oxygen-saturated $0.1 \mathrm{M} \mathrm{HClO}_{4}$ solution at room temperature. The RDE rotating rate was $1600 \mathrm{rpm}$ and sweep rate was $5 \mathrm{mV} / \mathrm{s}$. Current densities were normalized in reference to the geometric area of the GC RDE electrode $\left(0.196 \mathrm{~cm}^{2}\right)$. The CV measurements for accelerated durability tests (ADT) were conducted by potential cycling between 0.60 and $1.40 \mathrm{~V}$ in a $\mathrm{N}_{2}$ purged $0.1 \mathrm{M} \mathrm{HClO}_{4}$ solution at room temperature, with a scan rate of $50 \mathrm{mV} / \mathrm{s}$. In each case, ADT testing consisted of 30,000 cycles.

\section{Results and Discussion}

Figure 1(a) is an SEM image of the as-synthesized Nb- $\mathrm{TiO}_{2}$ nanostructures that clearly shows the hollow structures. The typical $\mathrm{Nb}-\mathrm{TiO}_{2}$ spheres have diameters of $100-150 \mathrm{~nm}$, which is the rutile phase confirmed by XRD analysis (JCPDS, 


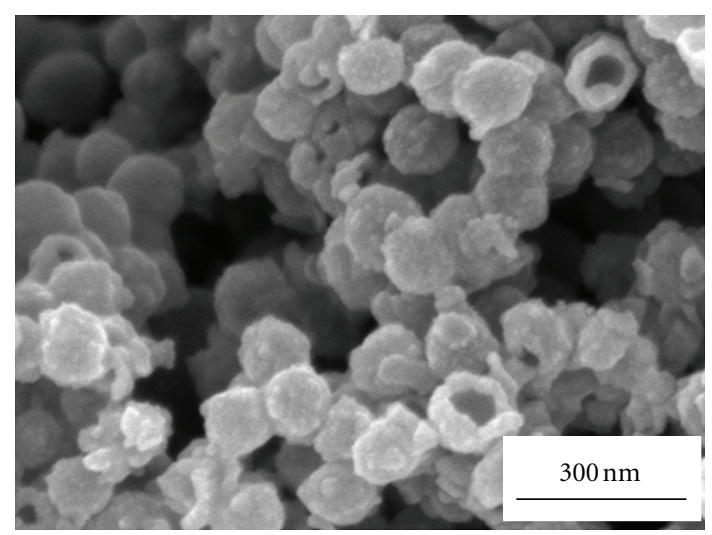

(a)

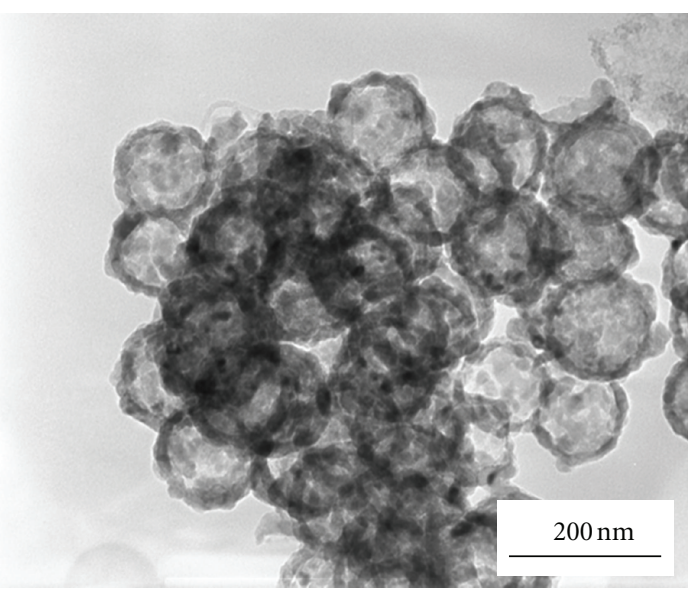

(c)

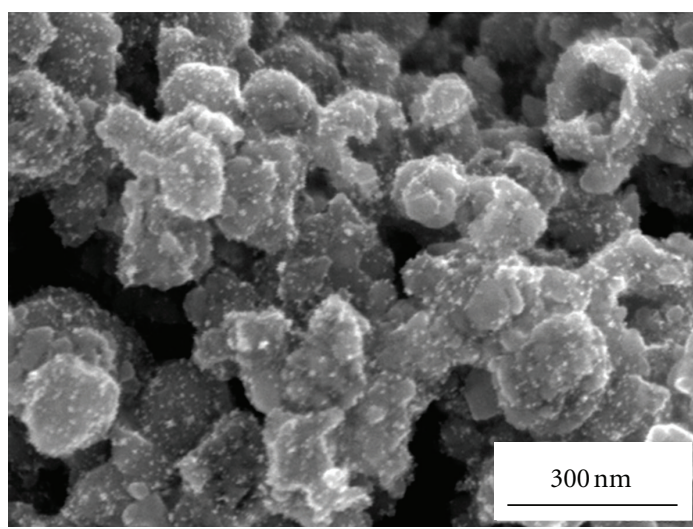

(b)

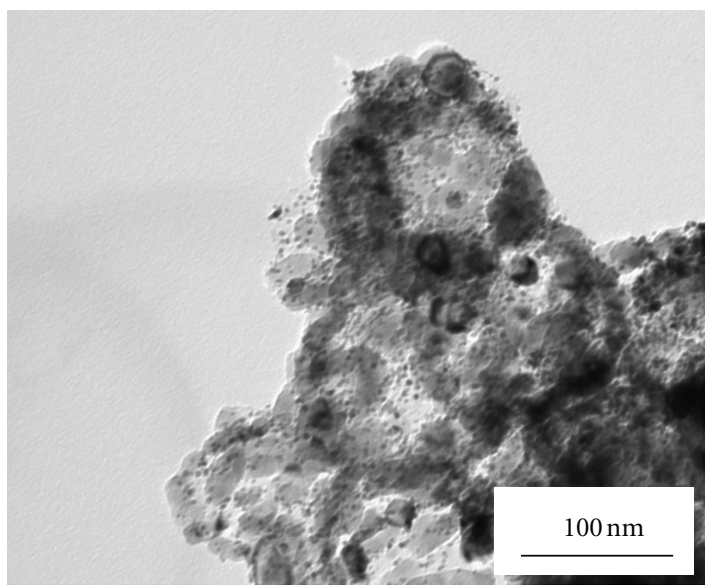

(d)

FIgure 1: SEM (a) and TEM (c) images pristine hollow Nb-TiO 2 nanostructures. SEM (b) and TEM (d) images Pt nanoparticles deposited on hollow $\mathrm{Nb}-\mathrm{TiO}_{2}$ nanostructures.

no. 21-1276, Figure S1, see Supplementary Material available online at doi:10.1155/2012/389505). The TEM image in Figure $1(\mathrm{c})$, further confirms that the shape of $\mathrm{Nb}-\mathrm{TiO}_{2}$ nanostructures with mesoporous shells are spherical and fairly uniform in size. Furthermore, each mesoporous shell is composed of small, 10-20 nm nanoparticles. Figures 1(b) and $1(\mathrm{~d})$ show the SEM and TEM images, respectively, of $\mathrm{Pt} \mathrm{NP} / \mathrm{Nb}-\mathrm{TiO}_{2}$ composite with $20 \mathrm{wt} \% \mathrm{Pt}$ loading. These images clearly display the homogeneous $\mathrm{Pt}$ deposition throughout the $\mathrm{Nb}-\mathrm{TiO}_{2}$ support. The average sizes of $\mathrm{Pt}$ nanoparticles on $\mathrm{Nb}-\mathrm{TiO}_{2}$ were obtained by measuring 100 randomly chosen nanoparticles under higher magnification TEM observation (Figure 2(a)). It is clearly seen that $\mathrm{Pt}$ nanoparticles with narrow size distribution have the mean size of $4 \mathrm{~nm}$. The selected area electron diffraction (SAED) patterns reveal the single crystallinity of both $\mathrm{Pt}$ nanoparticles and the $\mathrm{Nb}-\mathrm{TiO}_{2}$ support. High-resolution TEM (HRTEM) analysis (Figure 2(b)) further confirms the highly crystalline features of the support as well as Pt nanoparticles. The fringes with lattice spacing of $0.23 \mathrm{~nm}$ can be indexed as the (111) plane of face-centered-cubic (fcc) Pt, and the angle between two (111) planes also matches well with the fcc Pt.
The lattice spacing of $0.25 \mathrm{~nm}$ can be indexed to (101) plane of rutile $\mathrm{TiO}_{2}$.

The Pt loading can be readily tuned by simply changing the mass ratio of the precursor and support, while keeping the ratio between $\mathrm{Pt}$ precursor and $\mathrm{HCOOH}$ constant. Figure 3(a) shows a TEM image of the product resulting from a mass ratio of $\mathrm{H}_{2} \mathrm{PtCl}_{6}$ precursor to substrate $(\mathrm{Nb}$ $\mathrm{TiO}_{2}$ ) of $1: 9$, corresponding to $10 \mathrm{wt} \% \mathrm{Pt}$. At a higher mass ratio of $2: 3$, corresponding to $40 \mathrm{wt} \% \mathrm{Pt}$, the density of the Pt nanoparticles increases with some aggregation; however, their size remains consistent at approximately $4 \mathrm{~nm}$.

X-ray photoelectron spectroscopy (XPS) was employed to study the chemical composition and status of the product. Figure 4 shows the Pt 4f, Ti2p, Nb3d, and O1s high-resolution XPS spectra taken from $\mathrm{Pt} / \mathrm{Nb}-\mathrm{TiO}_{2}$ composites with different Pt loading levels (10, 20, and $40 \mathrm{wt} \% \mathrm{Pt}$ ), which were calibrated by placing the principal C 1 s peak at $284.8 \mathrm{eV}$. Obviously, continued weakening of the Ti2p signaled at 459.0 and $464.8 \mathrm{eV}, \mathrm{Nb} 3 \mathrm{~d}$ signaled at 207.6 and $210.3 \mathrm{eV}$, and $\mathrm{O} 1 \mathrm{~s}$ signaled at $532 \mathrm{eV}$ is accompanied by the continued strengthening of the Pt $4 \mathrm{f}$ signals at 71.1 and $74.4 \mathrm{eV}$ with increasing Pt content [24]. These results suggest that the surface of 


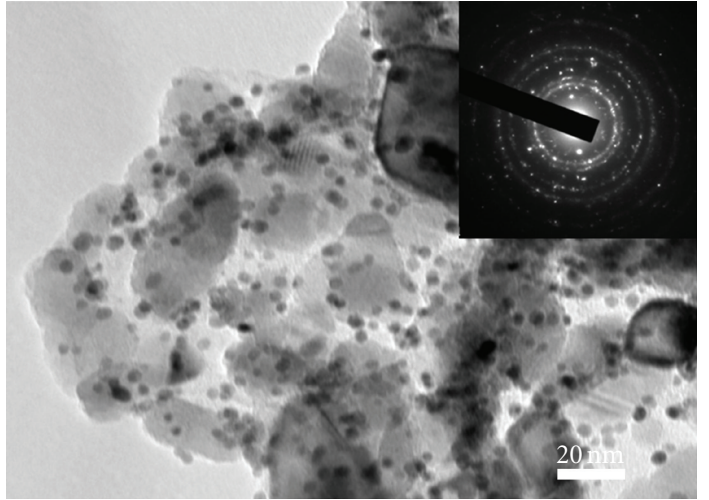

(a)

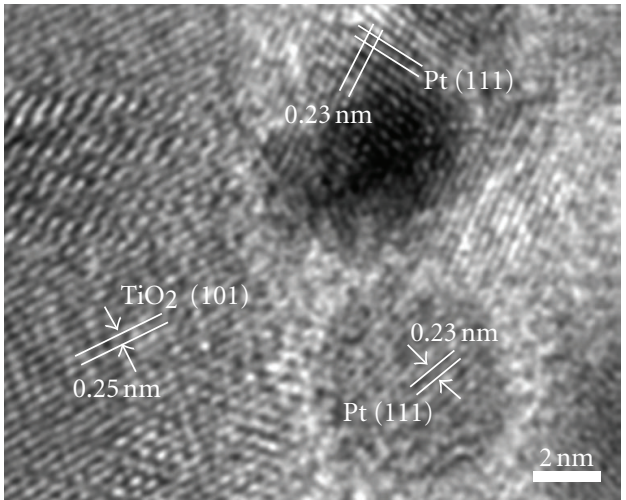

(b)

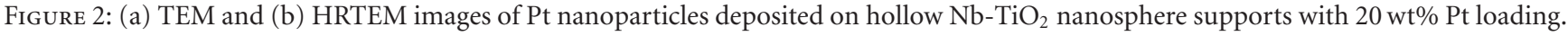
Pt NPs are single crystal, $4 \mathrm{~nm}$ in average size and uniformly dispersed on the surface of hollow $\mathrm{Nb}^{-\mathrm{TiO}_{2}}$ nanosphere supports.

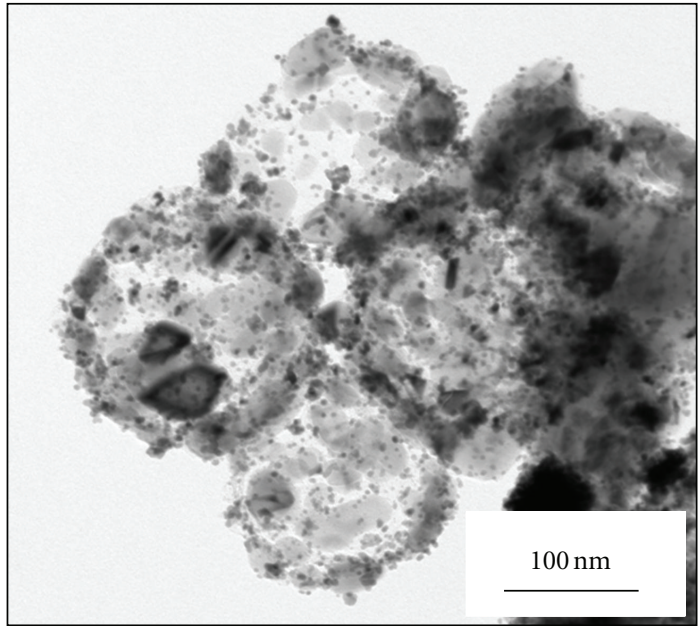

(a)

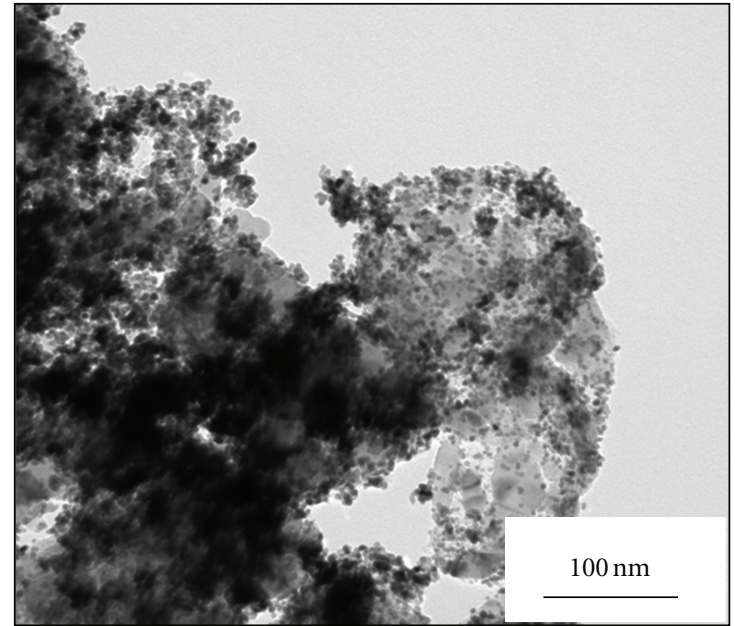

(b)

Figure 3: TEM images of Pt nanoparticles deposited on hollow $\mathrm{Nb}-\mathrm{TiO}_{2}$ nanosphere supports with different Pt loadings. (a) 10 wt $\%$ and (b) $40 \mathrm{wt} \%$.

the $\mathrm{Nb}-\mathrm{TiO}_{2}$ spheres becomes more covered with $\mathrm{Pt}$ nanoparticles that shield the $\mathrm{Nb}-\mathrm{TiO}_{2}$ surface from the XPS detection. The deconvolution of the Pt spectrum (inset in Figure 4(a)) shows only one doublet assigned as Pt 4f7/2 and $\mathrm{Pt} 4 \mathrm{f5} / 2$, which further confirms that the nanoparticles are pure metallic $\mathrm{Pt}$. We obtained a relative atomic concentration ratio $\mathrm{O}$ : Ti of 2 for the products from the experimental XPS peak areas, which further confirms that the support is $\mathrm{TiO}_{2}$ with 8 at $\% \mathrm{Nb}$ doping.

To study the electrochemical properties of the Pt NP/Nb$\mathrm{TiO}_{2}$ composites, electrochemical measurements were conducted with a glassy carbon electrode (GCE) modified by $\mathrm{Pt}$ $\mathrm{NPs} / \mathrm{Nb}-\mathrm{TiO}_{2}$ composites, with Pt loadings of 10, 20, and $40 \mathrm{wt} \%$, respectively. For comparison, a GCE supporting a commercial Pt/C catalyst (E-TEK) with $30 \mathrm{wt} \% \mathrm{Pt}$ loading was also tested. Figure 5(a) shows the cyclic voltammograms (CVs) of these fours catalysts recorded at room temperature in Ar-saturated $0.1 \mathrm{M} \mathrm{HClO}_{4}$ solution at a scan rate of
$20 \mathrm{mVs}^{-1}$. For all electrodes, the Pt loadings were kept at approximately $13.0 \mu \mathrm{gPt} / \mathrm{cm}^{2}$. The CVs show strong peaks characteristic of hydrogen adsorption/desorption peaks below $\sim 0.4 \mathrm{~V}$ and $\mathrm{Pt}$ oxidation/reduction peaks beyond $\sim 0.6 \mathrm{~V}$, and no considerable change in the shape is seen among these catalysts. The electrochemical surface areas (ECSAs) of Pt catalysts were determined by measuring the charge collected in the hydrogen $(\mathrm{H})$ adsorption/desorption region after double-layer correction and assuming a value of $210 \mu \mathrm{C} / \mathrm{cm}^{2}$ for the adsorption of a monolayer of hydrogen [20]. The obtained ECSAs for the four catalysts are listed in Table 1. We can see that commercial Pt/C catalyst (E-TEK) shows the largest electrochemical surface area (ECSA) with $57 \mathrm{~m}^{2} / \mathrm{gPt}$. The $40 \mathrm{wt} \% \mathrm{Pt} / \mathrm{Nb}-\mathrm{TiO}_{2}$ has $\mathrm{ECSA}$ value of $47 \mathrm{~m}^{2} / \mathrm{gPt}$, followed by the $10 \mathrm{wt} \%$ and $20 \mathrm{wt} \% \mathrm{Pt} / \mathrm{Nb}-\mathrm{TiO}_{2}$ which have ECSA values of $40 \mathrm{~m}^{2} / \mathrm{gPt}$ and $37 \mathrm{~m}^{2} / \mathrm{gPt}$, respectively. Interestingly, while there is no observed trend in $\mathrm{Pt}$ ECSA with the increasing $\mathrm{Pt}$ loading on $\mathrm{Nb}-\mathrm{TiO}_{2}$, it can 


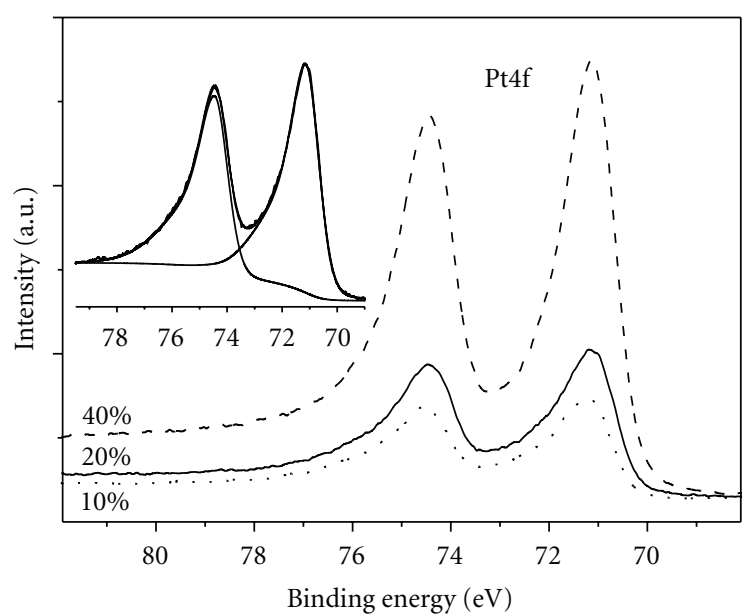

(a)

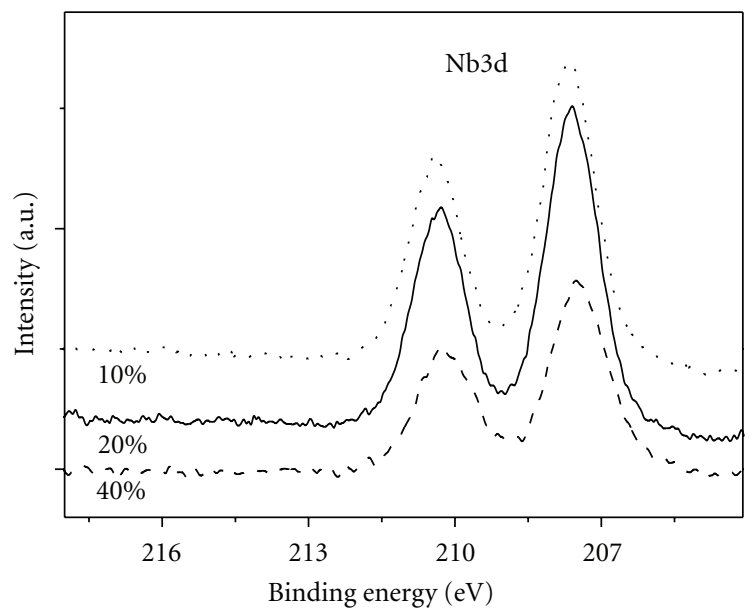

(c)

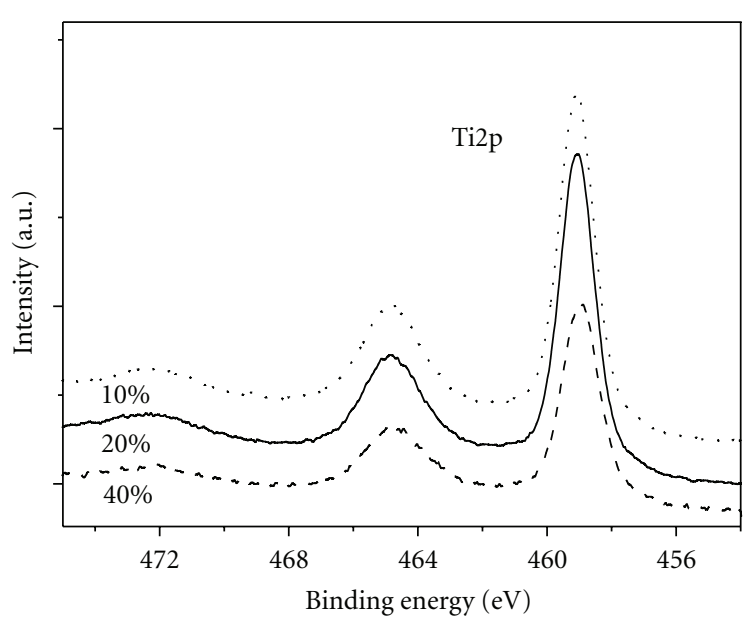

(b)

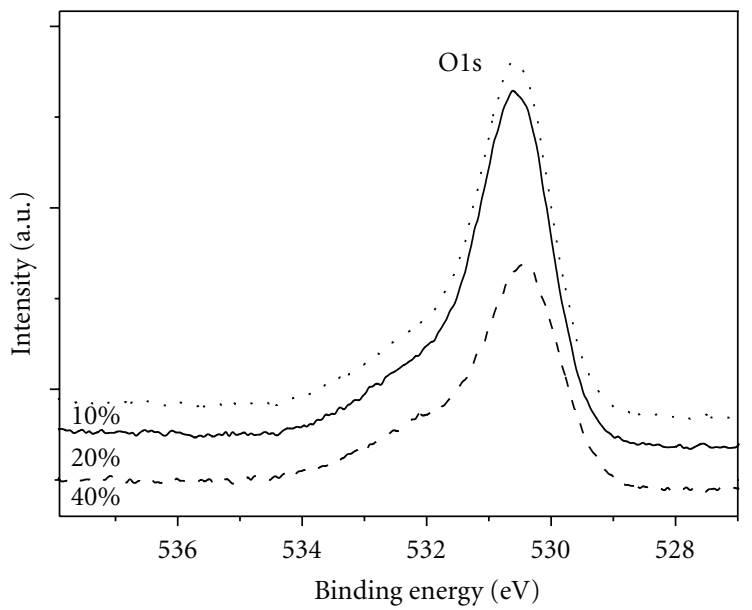

(d)

FIGURe 4: High-resolution XPS spectra of (a) Pt 4f; (b) Ti2p; (c) Nb3d; (d) O1S. Inset in (a) shows the corresponding deconvolution of Pt 4f spectrum.

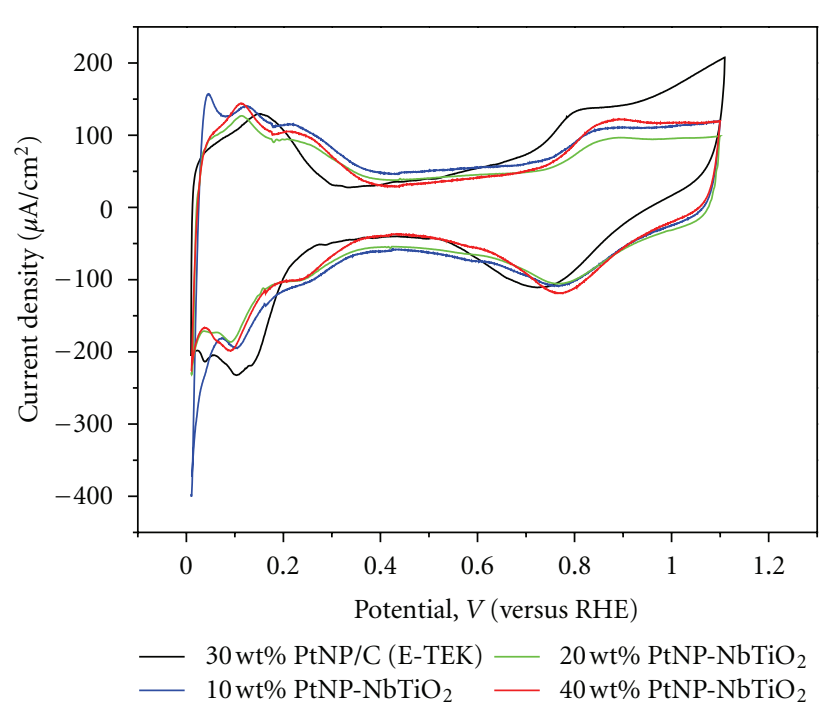

(a)

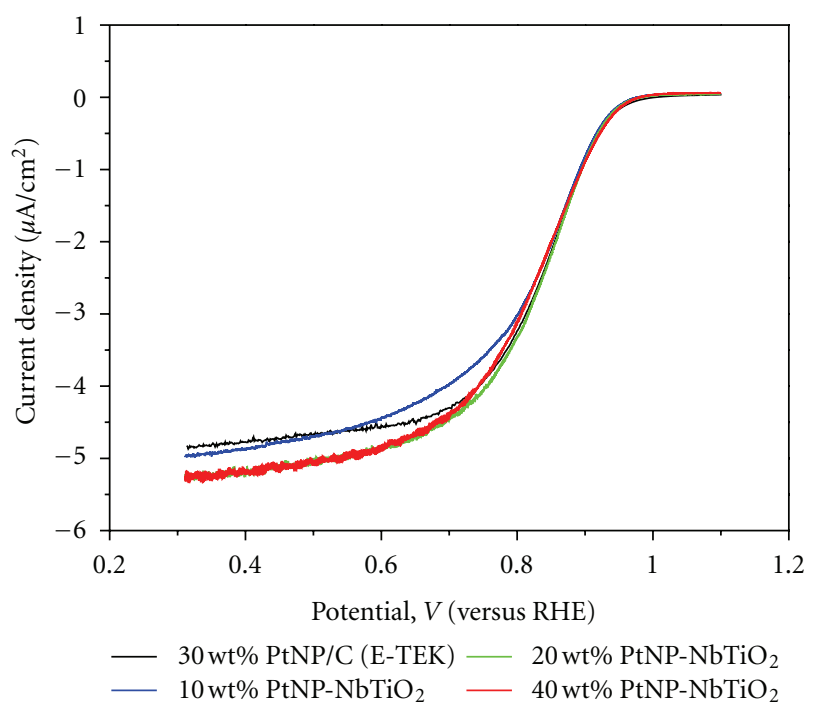

(b)

Figure 5: (a) CV curves and (b) polarization curves for $\mathrm{O}_{2}$ reduction on commercial ETEK Pt/C catalyst and $\mathrm{Nb}$-doped TiO ${ }_{2}$ with different Pt NP loadings in a $0.1 \mathrm{M} \mathrm{HClO}_{4}$ solution on a disk electrode. 


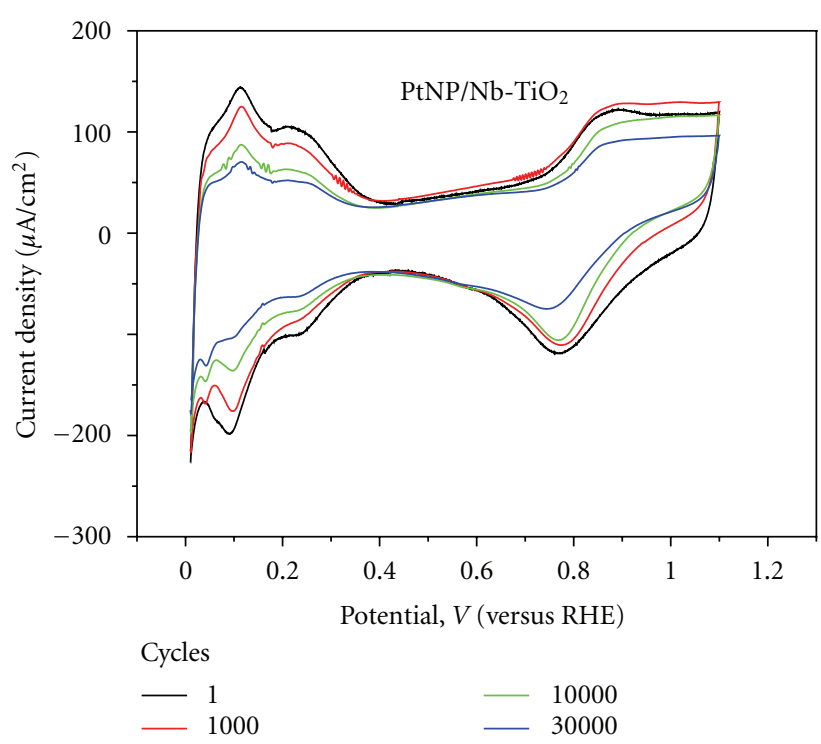

(a)

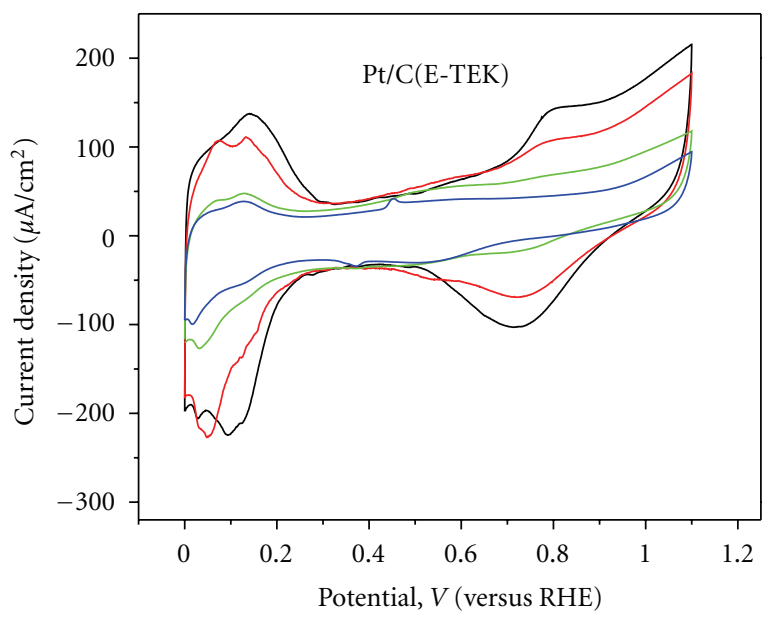

Cycles

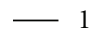

10000

(b)

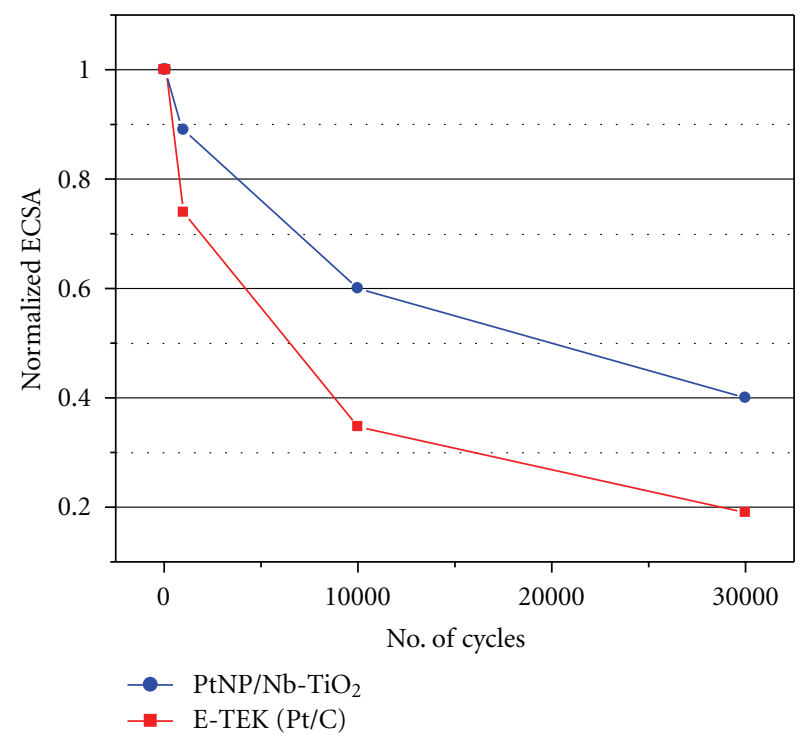

(c)

FIgure 6: Cyclic voltammograms recorded on (a) $\mathrm{PtNP} / \mathrm{Nb}-\mathrm{TiO}_{2}$ and (b) ETEK PtNP/C electrodes in $0.1 \mathrm{M}^{\mathrm{HClO}} \mathrm{H}_{4}$ solution at room temperature during ADT. (c) ECSAs as a function of cycling numbers on PtNP/Nb- $\mathrm{TiO}_{2}$ and ETEK PtNP/C electrodes.

be suggested that by this Pt deposition method, similar Pt particle size can be produced even at higher Pt loading on the metal oxide substrate.

Figure 5(b) shows the rotating disk measurements, at $1600 \mathrm{rpm}$, for the ORR on three $\mathrm{Pt} / \mathrm{Nb}-\mathrm{TiO}_{2}$ catalysts, along with the commercial $\mathrm{Pt} / \mathrm{C}$ catalyst (ETEK) for comparison. The corresponding electrochemical parameters are listed in Table 1. From the figure, the ORR on all catalysts is diffusion controlled when the potential is less than $0.7 \mathrm{~V}$ and is under mixed diffusion-kinetic control in the potential region between 0.7 and $0.85 \mathrm{~V}$. From Table 1, we can see that, as compared to the E-TEK Pt/C catalyst, $10 \mathrm{wt} \%$ PtNPs/ $\mathrm{NbTiO}_{2}$ composite shows the best performance with $15 \%$ and $63 \%$ higher mass and specific activities, respectively.
Furthermore, overall comparison of the ORR activities indicates that all the homemade $\mathrm{PtNPs} / \mathrm{Nb}-\mathrm{TiO}_{2}$ composites exhibit higher mass and specific activities than those of the commercial E-TEK Pt/C catalyst. This improvement in activity is significant considering $100 \mathrm{~m}^{2} / \mathrm{g}$ BET surface area [15] which is $2 / 5$ of that of Vulcan XC carbon support of commercial $\mathrm{Pt} / \mathrm{C}$ catalyst. The enhancement in the ORR activity might be due to the homogeneous distribution of small Pt nanoparticles and the mesoporous surface structure of the $\mathrm{TiO}_{2}$ hollow spheres.

The durability of the catalysts was determined in an accelerated durability test (ADT) by continuously applying linear potential sweeps from 0.60 to $1.4 \mathrm{~V}$ (versus RHE), causing surface oxidation/reduction of $\mathrm{Pt}$ and the oxidation 
TABle 1: Comparison of mass and specific activities for ORR and Pt electrochemical surface area of the different catalysts. All these three Pt $\mathrm{NP} / \mathrm{TiO}_{2}$ catalysts show better mass and specific activity than those of the state-of-the-art commercial Pt/C catalyst.

\begin{tabular}{|c|c|c|c|}
\hline Catalyst & $\begin{array}{c}\text { Mass activity at } 0.9 \mathrm{~V} \\
\mathrm{~A} / \mathrm{mg} \mathrm{Pt}\end{array}$ & $\begin{array}{l}\text { Electrochemical-specific surface area } \\
\qquad \mathrm{m}^{2} / \mathrm{g}\end{array}$ & $\begin{array}{c}\text { Specific activity at } 0.9 \mathrm{~V} \\
\mu \mathrm{A} / \mathrm{cm}^{2} \mathrm{Pt}\end{array}$ \\
\hline $\mathrm{PtNP} / \mathrm{C}$ (E-TEK) $30 \mathrm{wt} \% \mathrm{Pt}$ & 0.080 & 57 & 140 \\
\hline PtNP-NbTiO ${ }_{2} 10 \mathrm{wt} \% \mathrm{Pt}$ & 0.092 & 40 & 228 \\
\hline $\mathrm{PtNP}-\mathrm{NbTiO}_{2} 20 \mathrm{wt} \% \mathrm{Pt}$ & 0.082 & 37 & 223 \\
\hline $\mathrm{PtNP}-\mathrm{NbTiO}_{2} 40 \mathrm{wt} \% \mathrm{Pt}$ & 0.082 & 47 & 175 \\
\hline
\end{tabular}

of support. The surface reaction involves the formation of $\mathrm{PtOH}$ and $\mathrm{PtO}$ derived from the oxidation of water that causes the dissolution of $\mathrm{Pt}$ via the $\mathrm{Pt}^{2+}$ oxidation state $[25,26]$. The test was conducted by applying potential sweeps at scan rate of $50 \mathrm{mV} / \mathrm{s}$ in a $\mathrm{N}_{2}$ saturated, $0.1 \mathrm{M} \mathrm{HClO}_{4}$ solution at room temperature. For comparison, commercial E-TEK Pt/C (30 wt\% Pt) catalyst with a similar Pt loading as that in $\mathrm{Pt} / \mathrm{Nb}-\mathrm{TiO}_{2}(40 \mathrm{wt} \% \mathrm{Pt})$ was subjected to the same potential cycling conditions. It is generally believed that the performance degradation of the electrodes in PEMFC is mainly due to the ECSAs decrease of the catalysts. After 30,000 cycles, changes in the Pt ECSA were determined. As shown in Figures 6(a) and 6(b), cyclic voltammetry was used to determine the $\mathrm{Pt}$ surface area of $\mathrm{Pt} / \mathrm{Nb}-\mathrm{TiO}_{2}$ and $\mathrm{Pt} / \mathrm{C}$ electrodes by measuring the $\mathrm{H}$ adsorption before and after potential cycling. Figure 6(c) shows that, for $\mathrm{Pt} / \mathrm{Nb}-\mathrm{TiO}_{2}$, $\sim 40 \%$ of the original Pt surface area remained after 30,000 cycles potential cycling, which is 2.1 times higher than the $\sim 19 \%$ remaining for the commercial E-TEK Pt/C catalyst. These results reveal that the $\mathrm{Pt}$ on $\mathrm{Nb}-\mathrm{TiO}_{2}$ support is more electrochemically stable. The enhanced stability might be attributed to: (a) the higher corrosion resistance of $\mathrm{Nb}-\mathrm{TiO}_{2}$ support compared to carbon in acidic environments, (b) a strong Pt-metal oxide support interaction inhibiting the sintering of the Pt $[16,17]$.

\section{Conclusions}

In summary, we have demonstrated a facile wet-chemical method to grow single-crystalline Pt nanoparticles on mesoporous $\mathrm{Nb}$-doped $\mathrm{TiO}_{2}$ hollow spheres in aqueous solution, without using any surfactant. The use of $\mathrm{Nb}-\mathrm{TiO}_{2}$ hollow spheres as substrate provides a new type of cost-effective support with high corrosion resistance for growing Pt nanoparticles. The growth density of $\mathrm{Pt}$ nanoparticles on $\mathrm{Nb}$ $\mathrm{TiO}_{2}$ support could be controlled by manipulating the mass ratios between the $\mathrm{Pt}$ precursor and the $\mathrm{Nb}-\mathrm{TiO}_{2}$ support. $\mathrm{PtNP} / \mathrm{Nb}-\mathrm{TiO}_{2}$ catalysts show enhanced activity and stability compared with the commercial E-TEK Pt/C catalyst.

\section{Acknowledgments}

This research was supported by General Motors of Canada, Natural Sciences and Engineering Research Council of Canada (NSERC), Canada Research Chair (CRC) Program, Canada Foundation for Innovation (CFI), and Ontario Early
Researcher Award and the University of Western Ontario. S. Sun is grateful to the NSERC CGS scholarship and G. Zhang thanks the NSERC postdoctoral fellowship. The authors thank the help and discussion with Drs. P. Mani, M. Balogh, I. Butta, M. Militello, C. Wong, and X. Xiao.

\section{References}

[1] M. Marezio and P. D. Dernier, "The crystal structure of $\mathrm{Ti}_{4} \mathrm{O}_{7}$, a member of the homologous series $\mathrm{Ti}_{n} \mathrm{O}_{2 n-1}$, Journal of Solid State Chemistry, vol. 3, no. 3, pp. 430-348, 1971.

[2] R. Borup, J. Meyers, B. Pivovar et al., "Scientific aspects of polymer electrolyte fuel cell durability and degradation," Chemical Reviews, vol. 107, no. 10, pp. 3904-3951, 2007.

[3] D. A. Stevens and J. R. Dahn, "Thermal degradation of the support in carbon-supported platinum electrocatalysts for PEM fuel cells," Carbon, vol. 43, no. 1, pp. 179-188, 2005.

[4] Y. Shao, G. Yin, and Y. Gao, "Understanding and approaches for the durability issues of Pt-based catalysts for PEM fuel cell," Journal of Power Sources, vol. 171, no. 2, pp. 558-566, 2007.

[5] M. S. Saha, R. Li, and X. Sun, "High loading and monodispersed Pt nanoparticles on multiwalled carbon nanotubes for high performance proton exchange membrane fuel cells," Journal of Power Sources, vol. 177, no. 2, pp. 314-322, 2008.

[6] T. Ioroi, H. Senoh, S. I. Yamazaki, Z. Siroma, N. Fujiwara, and K. Yasuda, "Stability of corrosion-resistant Magńli-phase $\mathrm{Ti}_{4} \mathrm{O}_{7}$-supported PEMFC catalysts at high potentials," Journal of the Electrochemical Society, vol. 155, no. 4, pp. B321-B326, 2008.

[7] T. Ioroi, Z. Siroma, N. Fujiwara, S. I. Yamazaki, and K. Yasuda, "Sub-stoichiometric titanium oxide-supported platinum electrocatalyst for polymer electrolyte fuel cells," Electrochemistry Communications, vol. 7, no. 2, pp. 183-188, 2005.

[8] H. Chhina, S. Campbell, and O. Kesler, "An oxidation-resistant indium tin oxide catalyst support for proton exchange membrane fuel cells," Journal of Power Sources, vol. 161, no. 2, pp. 893-900, 2006.

[9] G. Chen, S. R. Bare, and T. E. Mallouk, "Development of supported bifunctional electrocatalysts for unitized regenerative fuel cells," Journal of the Electrochemical Society, vol. 149, no. 8, pp. A1092-A1099, 2002.

[10] H. Chhina, S. Campbell, and O. Kesler, "Ex situ evaluation of tungsten oxide as a catalyst support for PEMFCs," Journal of the Electrochemical Society, vol. 154, no. 6, pp. B533-B539, 2007.

[11] M. S. Saha, M. N. Banis, Y. Zhang et al., "Tungsten oxide nanowires grown on carbon paper as Pt electrocatalyst support for high performance proton exchange membrane fuel cells," Journal of Power Sources, vol. 192, no. 2, pp. 330-335, 2009. 
[12] M. S. Saha, R. Li, M. Cai, and X. Sun, "High electrocatalytic activity of platinum nanoparticles on $\mathrm{SnO} 2$ nanowire-based electrodes," Electrochemical and Solid-State Letters, vol. 10, no. 8, pp. B130-B133, 2007.

[13] M. D. Koninck, P. Manseau, and B. Marsan, "Preparation and characterization of $\mathrm{Nb}$-doped $\mathrm{TiO}_{2}$ nanoparticles used as a conductive support for bifunctional $\mathrm{CuCo}_{2} \mathrm{O}_{4}$ electrocatalyst," Journal of Electroanalytical Chemistry, vol. 611, no. 1-2, pp. 6779, 2007.

[14] K. W. Park and K. S. Seol, "Nb-TiO 2 supported Pt cathode catalyst for polymer electrolyte membrane fuel cells," Electrochemistry Communications, vol. 9, no. 9, pp. 2256-2260, 2007.

[15] M. Cai, Y. Lu, Z. Wu et al., "Making electrocatalyst supports for fuel cells," US patent, Application number: 12/716360, 2010.

[16] H. Chhina, D. Susac, S. Campbell, and O. Kesler, "Transmission electron microscope observation of Pt deposited on $\mathrm{Nb}$ doped titania," Electrochemical and Solid-State Letters, vol. 12, no. 6, pp. B97-B100, 2009.

[17] S. J. Tauster, S. C. Fung, and R. L. Garten, "Strong metal-support interactions. Group 8 noble metals supported on $\mathrm{TiO}_{2}$," Journal of the American Chemical Society, vol. 100, no. 1, pp. 170-175, 1978.

[18] F. Leroux, P. J. Dewar, M. Intissar, G. Ouvrard, and L. F. Nazar, "Study of the formation of mesoporous titania via a template approach and of subsequent Li insertion," Journal of Materials Chemistry, vol. 12, no. 11, pp. 3245-3253, 2002.

[19] E. Traversa, M. L. Di Vona, S. Licoccia et al., "Sol-gel processed $\mathrm{TiO}_{2}$-based nano-sized powders for use in thick-film gas sensors for atmospheric pollutant monitoring," Journal of SolGel Science and Technology, vol. 22, no. 1-2, pp. 167-179, 2001.

[20] S. H. Sun, D. Q. Yang, D. Villers, G. X. Zhang, E. Sacher, and J. P. Dodelet, "Template- and surfactant-free room temperature synthesis of self-assembled 3D Pt nanoflowers from singlecrystal nanowires," Advanced Materials, vol. 20, no. 3, pp. 571574, 2008.

[21] D. Q. Yang, S. Sun, J. P. Dodelet, and E. Sacher, "A facile route for the self-organized high-density decoration of Pt nanoparticles on carbon nanotubes," Journal of Physical Chemistry C, vol. 112, no. 31, pp. 11717-11721, 2008.

[22] D. Q. Yang, S. H. Sun, H. Meng, J. P. Dodelet, and E. Sacher, "Formation of a porous platinum nanoparticle froth for electrochemical applications, produced without templates, surfactants, or stabilizers," Chemistry of Materials, vol. 20, no. 14, pp. 4677-4681, 2008.

[23] http://www.phy.cuhk.edu.hk/ surface/XPSPEAK/.

[24] F. Moulder, W. F. Stickle, P. E. Sobol, and K. D. Bomben, Handbook of X-Ray Photoelectron Spectroscopy, Perkin-Elmer, Eden Prairie, Eden Prairie, Minn, USA, 1992, Edited by J. Chastain.

[25] R. Woods, Electroanalytical Chemistry, Marcel Dekker, New York, NY, USA, 1976, Edited by A. J. Bard.

[26] J. Zhang, K. Sasaki, E. Sutter, and R. R. Adzic, "Stabilization of platinum oxygen-reduction electrocatalysts using gold clusters," Science, vol. 315, no. 5809, pp. 220-222, 2007. 

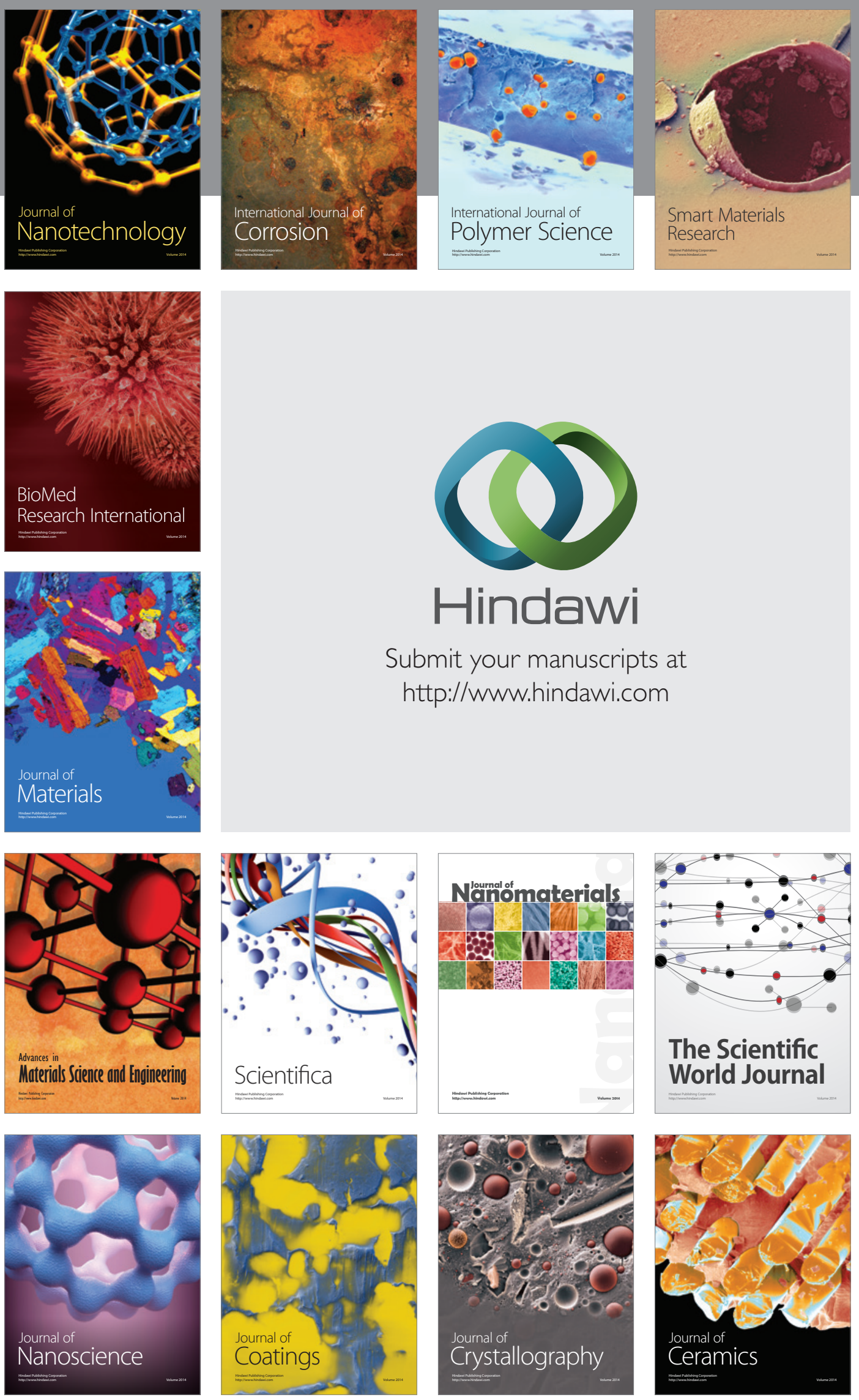

The Scientific World Journal

Submit your manuscripts at

http://www.hindawi.com

\section{World Journal}

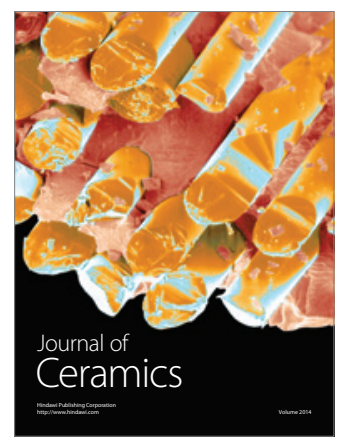

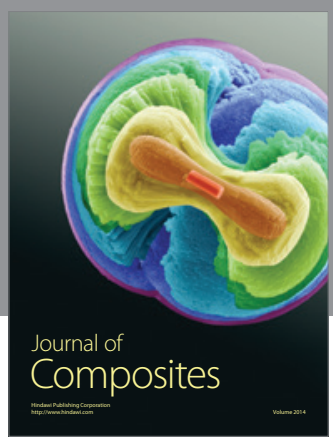
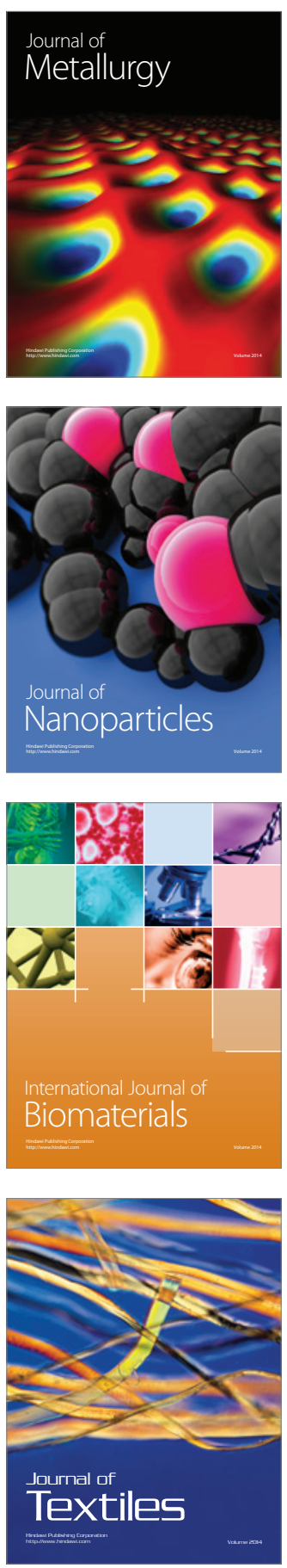